\title{
Review of Une vie brève by Michèle Audin
}

\author{
Laurent Mazliak
}

Published online: 26 July 2013

(c) Centro P.RI.ST.EM, Università Commerciale Luigi Bocconi 2013

\begin{abstract}
In France the tragic story of Maurice Audin is by now relatively well-known but the originality of the touching book by Michèle Audin lies in the introspective nature of the account, seen through the eyes of his daughter.
\end{abstract}

\section{Keywords Maurice Audin · Michèle Audin}

We often too easily forget that a mathematician is first and foremost a human being who lives immersed in his epoch. It is obvious that, when the times are dramatic, his life is less identified with his professional activities, because he is involved to a greater extent in struggles, doubts and, sometimes, suffering. This was the case of Maurice Audin, a young assistant in mathematics in the University of Algiers during the late 1950s, when began the war in Algeria. A member of the Algerian Communist Party and a staunch supporter of the independence of Algeria, in June 1957, shortly before he was to defend his doctoral thesis in linear algebra, he was arrested by the French army, without a warrant, and thus in violation of all juridical principles. He was never seen again. Still today in France the circumstances of his death, which almost certainly occurred within a few days after his arrest as a result of torture, remain shrouded in mystery because the files are still classified, a cover-up against which Audin's widow fought incessantly for 50 years. After Audin's disappearance, thanks above all the efforts of Laurent Schwartz, his thesis was defended in absentia, on 2 December 1957 (Fig. 1).

L. Mazliak ( $₫)$

LPMA Université Pierre et Marie Curie, Case Courrier 188, 4, Place Jussieu, 75252 Paris Cedex 05, France

e-mail: laurent.mazliak@upmc.fr
In France this story is by now relatively well-known to the general public; it is certainly well known to mathematicians. But the originality of the touching book by Michèle Audin [1] lies in the introspective nature of the account, seen through the eyes of his daughter. The book does not ask for a settling of the score, nor does it make any direct accusations. It is only the enquiry of a woman into the life of her own father, brutally arrested when she was just a child. Michèle Audin had to delve into her memory and evoke her oldest recollections in order to relive her relationship with her father and describe how, in spite of his absence, their rapport was never interrupted. Just when she had promised herself that this painful past would not interfere with her mathematical career, some of her colleagues forced her in a certain sense to think about her father again, and thus, in a stroke, his image emerged from the fog of the past, and Michèle saw him as he smiled and called to her.

Reading this book, one is almost surprised by the serene tone of a writing style that is calm and lacking in pathos. The period of ire seems to have passed, like that of the most intense pain, due in part to the promise made by the president of the French Republic during his recent trip to Algeria, to open the archives and shed light on the tragic events. The pages of the book are the fruit of the reconstruction of events in the life of a person in flesh and blood, beyond his legend, a process that for Michèle Audin - as we know by other historical works of hers about Sofia Kovalevskaya and André Weil - is not a new one. The historical research allows us to know what life was like for a young man in the middle of the twentieth century, during the difficult years of occupation, of post-war reconstruction, of growing tension in Algeria and, naturally, of the marvellous discovery of mathematics. Maurice Audin, born into a normal family whose members were farmers, manual 


\section{Michèle Audin}

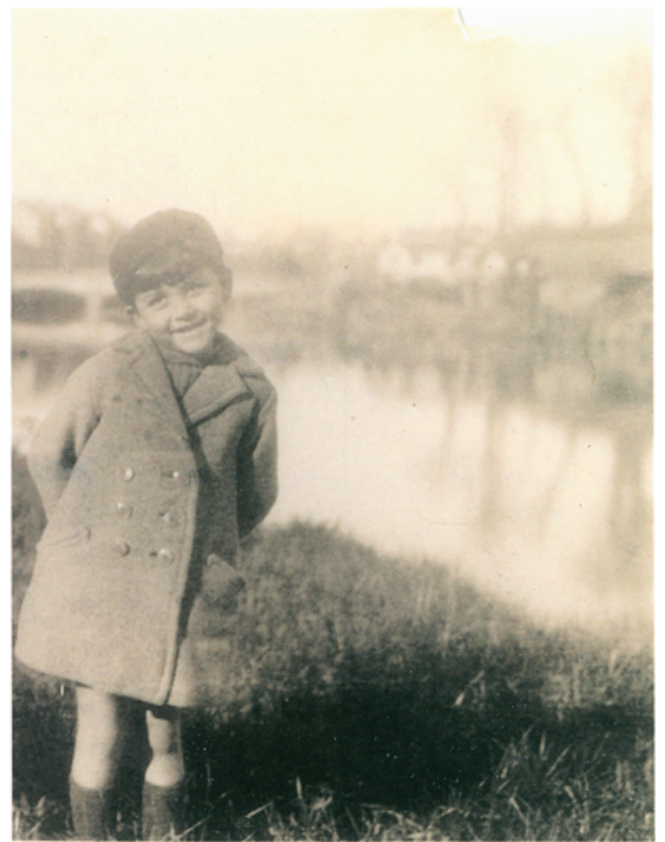

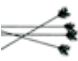

l'arbalète gallimard récit

\section{Une vie brève}

Fig. 1 Une vie brève by Michèle Audin

labourers or career military men. The sentiment of his family with regard to the army was due to the fact that he completed his studies together with the sons of soldiers under French military authority in Algeria. By a cruel twist of fate, this same military authority was to become the cause of his death. Michèle Audin describes for us the atmosphere in the faculty of sciences in Algiers, Audin's study of mathematics, his involvement with the Communists and all the rest: the reactions of family members who were strongly attached to the idea of a French Algeria, the arguments, the cowardice of some and the courage of others who refused to remain silent.

Today the only thing that remains of all this is a few folders of yellowing photographs, letters and administrative documents from which derive information that, like the brush strokes of an impressionist painting, provide us with a portrait that is slightly blurred. We smile bitterly, for example, when we learn from the pen of the daughter that she now knows perfectly her father's social security number but not how tall he was. By the book's end we are aware of having met a man in the flower of his years, one of whom not even tragic death could cancel his existence and memory. This is a bittersweet voyage. Before his cruel death turned him into a symbol, Maurice Audin was a brilliant man who loved life. His daughter is a meaningful embodiment of this.

\section{Reference}

1. Audin, M.: Une vie brève. L'arbalète Gallimard, Paris (2012)

\section{Author Biography}

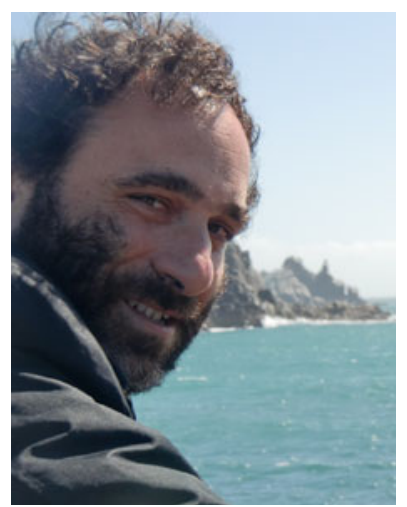

Laurent Mazliak mathematician and historian is member of the Laboratoire de Probabilités et Modèles Aléatoires of University Pierre and Marie Curie, Paris. His research concerns the history of probability at the beginning of the twentieth century, and in particular the impact of the Great War on the European mathematical communities. 